\title{
$\mathrm{PCB}$ 에 인가된 스위칭 잡음이 함체 개구 방사에 미치는 영향
}

\section{Effect of PCB Switching Noise on Radiated Emission from Enclosure Aperture}

\author{
장형석 · 이숭근 · 김은하* · 유승렬* · 이재현 · 박동철 \\ Hyoung Seok Jang - Soong Keun Lee - Eun Ha Kim* - Seung Real Ryu* • \\ Jae-Hyun Lee $\cdot$ Dong Chul Park
}

요 약

본 논문은 능동 소자의 스위칭 잡음이 함체 내부에 위치한 $\mathrm{PCB}$ 에 인가될 때, 함체의 개구 방사에 미치는 영향을 분석한 연구이다. 이상적인 주기 펄스 입력 신호가 $\mathrm{PCB}$ 에 인가된 경우의 개구 방사와 스위칭 잡음을 포함한 주기 입력 신호가 인가된 경우의 개구 방사를 비교하였다. DC-DC 컨버터의 등가회로를 이용해 능동 소자의 스위칭 잡음을 구현하였으며, 방사 전계 시뮬레이션을 위해 회로 시뮬레이터와 전자기장 시뮬레이터를 연동시켜 해석을 수행하였다. 또한, 측정 결과와 시뮬레이션 결과를 비교하였다.

\section{Abstract}

This paper investigates the radiated emission from the enclosure aperture, when the enclosure contains a 4-layer PCB and the PCB is driven by a pulse train additive with the switching noise from an active device. Radiated emission characteristics with and without switch noise cases, respectively, are analyzed by changing the PCB location and the slot direction. The equivalent circuit of a DC-DC converter is used to simulate the switching noise of active device. Also, MWS simulation results are directly connected to the ADS simulator as a 2-port block. The simulated results are compared with the measured ones.

Key words : PCB, Switching Noise, Radiated Emission, Enclosure Aperture

\section{I. 서 론}

함체는 일반적으로 전원선, 신호선 등을 위한 개 구와 냉각용으로 사용하기 위한 개구 등 많은 종류 의 개구를 가지게 되며, 개구를 통하여 방사된 전자 파는 다른 기기에 오작동을 유발하거나 인체에 영향 을 끼치는 등 많은 문제를 야기할 수 있다. 따라서 기기 내부에서 발생하는 함체 공진 특성을 예측하 고, 이를 감소시키는 연구가 필요하다. 함체로부터
방사되는 전자파의 저감에 관한 연구는 함체 내부에 소스원이 있을 경우, 개구를 통해 외부로 방사되는 전자파에 대한 해석 ${ }^{[1]}\left[{ }^{[3]}\right.$ 이나 외부의 전자파가 개구 를 통해 함체 내부로 침투할 때의 차폐 효과를 해석 한 내용 ${ }^{[4]}$ 이다. 위의 연구들은 함체 내부에 전자파를 측정하기 위한 프로브 만을 놓아두고 함체 내부가 비어있는 상황에서 연구를 수행하였다. 좀 더 실제 적인 접근을 위해 함체 내부에 $\mathrm{PCB}$ 를 설치하고, $\mathrm{PCB}$ 의 위치에 따른 개구 방사에 대한 연구다와 함체

\footnotetext{
「본 연구는 2010년도 지식경제부의 재원으로 한국에너지기술평가원(KETEP)의 지원을 받아 수행한 연구 과제입니다(No. 2009T100200647).」

충남대학교 전파공학과(Department of Radio Science \& Engineering, Chungnam National University)

*자동차부품연구원(Korea Automotive Technology Institute)

·논 문 번 호 : 20101026-152

- 교 신 저 자 : 박동철(e-mail : dcpark@cnu.ac.kr)

· 수정완료일자 : 2010년 12월 24일
} 
개구의 방향에 따른 개구 방사 연구 ${ }^{[6]}$ 가 필자들에 의 해 보고된 바 있다.

본 논문에서는 참고문헌 [5]와 [6]에서의 연구를 바탕으로 능동 소자의 스위칭에 의한 잡음이 포함된 신호를 입력으로 받는 PCB가 slot 개구를 갖는 함체 내에 존재할 때 $\mathrm{PCB}$ 의 함체 내 위치 및 slot 개구의 방향에 따른 방사 특성에 대해 분석한다.

\section{Radiated Emission 모델}

그림 1 은 본 연구에 사용된 $\mathrm{PCB}$ 와 함체를 보여 준다. $\mathrm{PCB}$ 는 4 층 기판의 마이크로스트립 구조를 가 지며, 입출력 포트는 $\mathrm{CPWG}$ (Coplanar Waveguide With Ground)구조이다. 또한, 전원면과 접지면을 연결하 기 위해 ground via가 사용되었다. Via의 간격은 $3 \mathrm{~mm}$ 로 설정하였고, $\mathrm{PCB}$ 의 크기는 $50 \mathrm{~mm} \times 22 \mathrm{~mm}$ 이며, 유전율 4.4인 FR-4 기판의 두께는 $1.2 \mathrm{~mm}$ 이다. 시뮬 레이션 시, PCB 2개의 포트 중 한 포트에는 입력 신 호를 넣어주고, 다른 한 쪽은 종단을 해준 후 함체 밖 원거리장에 필드 프로브를 놓아 방사 세기를 계 산하였다. 함체의 내부 크기는 $150 \mathrm{~mm} \times 75 \mathrm{~mm} \times 20$ $\mathrm{mm}$ 이고, 재질은 두께가 $4 \mathrm{~mm}$ 인 알루미늄이며, slot 개구의 크기는 $50 \mathrm{~mm} \times 4 \mathrm{~mm} \times 4 \mathrm{~mm}$ 이다.

Rectangular cavity의 공진 주파수는 식 (1)로 계산 되며 ${ }^{[7]}$, 표 1 은 식 (1)을 이용하여 계산된 함체의 공

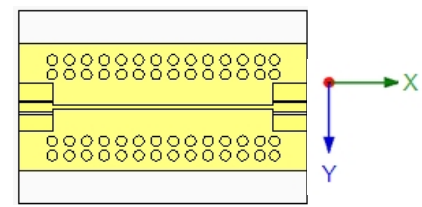

(a) PCB

(a) $\mathrm{PCB}$

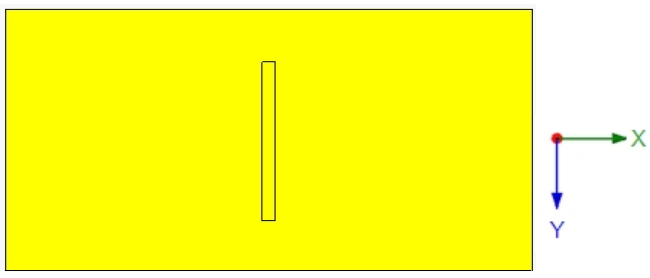

(b) Slot 개구가 있는 함체

(b) Enclosure with slot aperture

그림 1. $\mathrm{PCB}$ 와 함체의 top view

Fig. 1. Top view of the PCB and enclosure.
표 1. 함체의 공진 주파수

Table 1. Resonance frequencies of enclosure.

\begin{tabular}{|c|c|}
\hline Mode $(m, n, l)$ & Frequency $[\mathrm{GHz}]$ \\
\hline $\mathrm{TE}(1,1,0)$ & 2.236 \\
\hline $\mathrm{TE}(2,1,0)$ & 2.828 \\
\hline $\mathrm{TE}(3,1,0)$ & 3.606 \\
\hline $\mathrm{TE}(1,2,0)$ & 4.123 \\
\hline $\mathrm{TE}(2,2,0)$ & 4.472 \\
\hline $\mathrm{TE}(2,3,0)$ & 5.000 \\
\hline
\end{tabular}

진 주파수이다. TM 모드의 경우 dominant 모드는 $(0$, $1,1)$ 모드이고, 공진은 $7.762 \mathrm{GHz}$ 에서 발생한다. 따 라서 우리가 관심을 가지고 있는 $0 \sim 5 \mathrm{GHz}$ 범위 내 에서는 TE 모드만 존재해 TE 모드의 공진 주파수만 보였다.

$$
f_{r}=\frac{3 \times 10^{8}}{2 \pi \sqrt{\mu \epsilon}} \sqrt{\left(\frac{m \pi}{a}\right)^{2}+\left(\frac{n \pi}{b}\right)^{2}+\left(\frac{l \pi}{c}\right)^{2}}
$$

여기서 $a, b, c$ 는 각각 함체 내부의 가로 $(150 \mathrm{~mm})$, 세 로 $(75 \mathrm{~mm})$, 높이 $(20 \mathrm{~mm})$ 이며, $m, n, l$ 은 각각 가로 $(\mathrm{x}$ 방향), 세로(y 방향), 높이(z 방향) 방향으로의 모드 수이다.

함체 내 $\mathrm{PCB}$ 의 위치에 따른 방사 세기의 변화를 고찰하기 위해 그림 2처럼 함체 내 $\mathrm{PCB}$ 의 위치를 변 화시켰다. Case 1은 PCB가 함체의 가장자리 위치한 경우이며, Case 2는 함체의 중앙에 위치한 경우이다. 두 경우 공히 $z$ 축 방향으로는 $\mathrm{PCB}$ 가 함체의 정중앙 에 위치하며, Case 1과 Case 2의 차이는 $\mathrm{x}$ 축과 $\mathrm{y}$ 축 좌표 값 변화만으로 한정했다. 함체 위 slot 개구의 크기는 $50 \mathrm{~mm} \times 4 \mathrm{~mm}$ 이고, slot이 그림 3처럼 $\mathrm{x}$ 축 또 는 $\mathrm{y}$ 축 방향으로만 있는 두 가지 경우에 대해 고찰 하였다.

그림 4는 함체 공진이 나타나는 주파수에서 함체

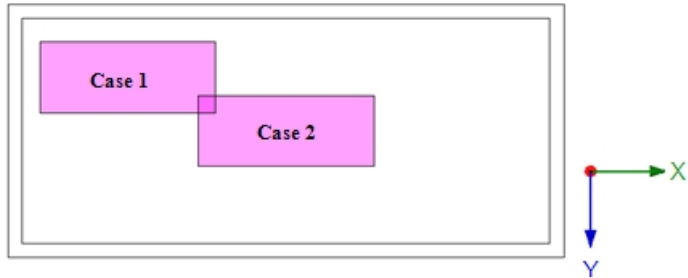

그림 2. 함체 내 $\mathrm{PCB}$ 의 위치

Fig. 2. PCB location in the enclosure. 


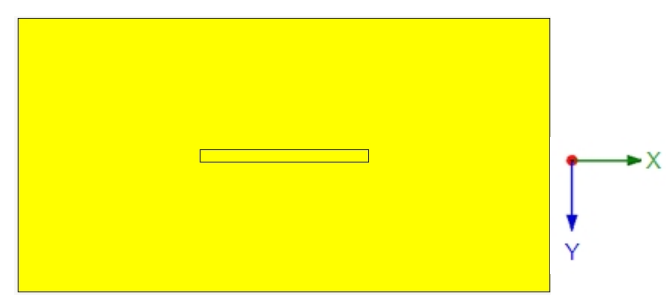

(a) $x$ 축 방향 slot 개구

(a) $x$-direction slot

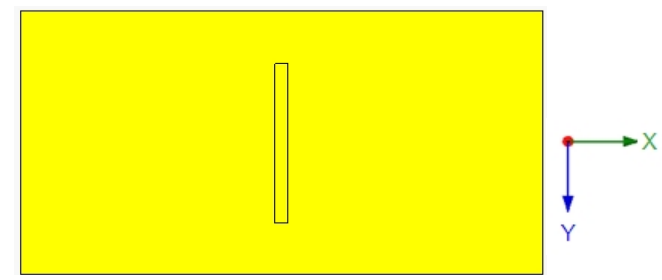

(b) y축 방향 slot 개구

(b) y-direction slot

그림 3. Slot 개구의 방향

Fig. 3. Direction of the slot aperture.

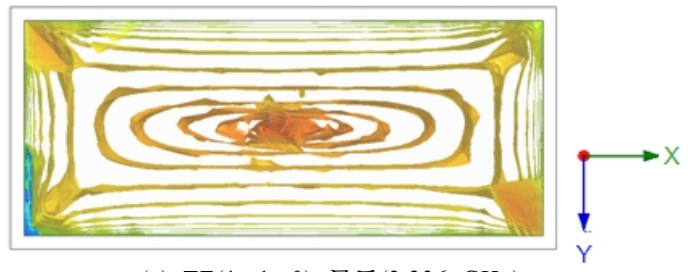

(a) $\mathrm{TE}(1,1,0)$ 모드 $(2.236 \mathrm{GHz})$

(a) $\mathrm{TE}(1,1,0) \operatorname{mode}(2.236 \mathrm{GHz})$

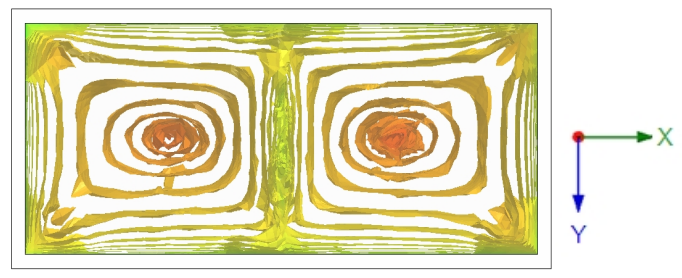

(b) $\mathrm{TE}(2,1,0)$ 모드 $(2.828 \mathrm{GHz})$

(b) $\mathrm{TE}(2,1,0) \operatorname{mode}(2.828 \mathrm{GHz})$

그림 4. 함체 내부의 파동 임피던스 분포

Fig. 4. Wave impedance distribution in the enclosure.

내부의 파동 임피던스 분포를 보여 준다. 파동 임피 던스는 아래의 식에 의해 나타낼 수 있다.

$$
Z=\frac{E}{H}
$$

전자기장 시뮬레이터와 회로 시뮬레이터를 연동 시킬 때 전자기장 시뮬레이터에서 구현한 구조물의

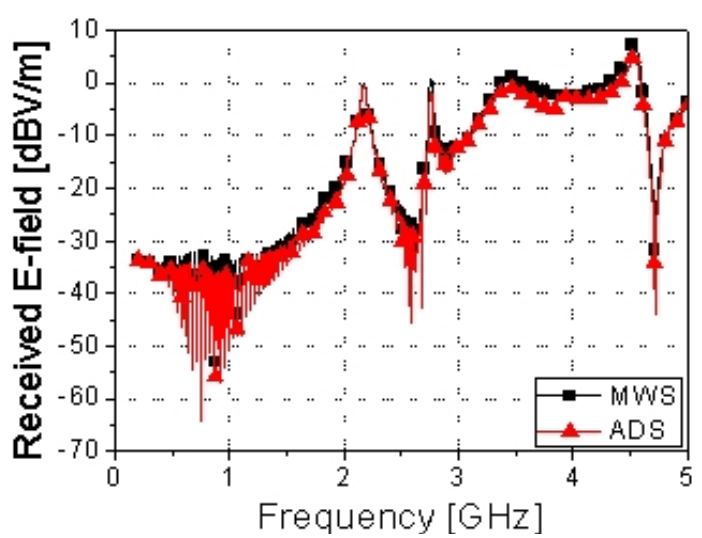

그림 5. MWS와 $\mathrm{ADS}$ 시뮬레이션 결과 비교

Fig. 5. Comparison of MWS and ADS simulation results.

주파수 영역 전달 함수 데이터 파일을 회로 시뮬레 이터의 N-포트 블록에 불러들여 사용하는 방법이 종 종 사용되고 있다 ${ }^{[8]}$. 본 논문에서도 MWS에서 구현 한 $\mathrm{PCB}$ 의 입력 포트를 포트 1로, 원거리장에 위치시 킨 프로브를 포트 2로 하여 전달 함수를 추출한 뒤, 회로 시뮬레이터인 $\mathrm{ADS}$ 의 2-포트 블록을 사용하였 다. MWS가 임펄스 입력을 토대로 주파수 전달 함수 를 얻게 해주고, 이를 $\mathrm{ADS}$ 의 2-포트 블록에 적용하 여 시간 영역 또는 주파수 영역 시뮬레이션을 수행 한다. 그림 5 는 위와 같은 과정을 우리의 문제에 적 용한 경우, $\mathrm{PCB}$ 가 Case 2 위치에 있고, 함체가 $\mathrm{y}$ 축 방향의 slot 개구를 가질 때의 MWS 시뮬레이션 결 과와 $\mathrm{ADS}$ 시뮬레이션 결과를 나타낸 것이다. 두 그 래프가 잘 일치하는 것을 확인할 수 있다.

\section{III. 스위칭 잡음 시뮬레이션}

잡음이 없는 주기 펄스를 $\mathrm{PCB}$ 의 입력으로 사용하 였을 경우와 스위칭 잡음이 섞인 신호를 입력으로 사용하였을 경우의 방사 세기의 변화를 알아보자.

MWS에서 추출한 데이터는 주파수 영역에서 얻 어진 것이므로 $\mathrm{ADS}$ 에서도 주파수 영역으로 결과 값 을 나타내어야 비교가 가능하다. 따라서 $\mathrm{ADS}$ 상의 $\mathrm{fs}$ 함수 기능을 이용하여 시간 영역 결과를 주파수 영역 결과로 변환시켰다. 그림 6(a)는 스위칭 잡음이 섞이 지 않은 주기 펄스 입력 신호를 나타낸 것이고, 그림 6(b)는 그 신호를 퓨리에 변환하여 나타낸 것이다.

그림 7은 스위칭 잡음이 없는 그림 6의 주기 신호 


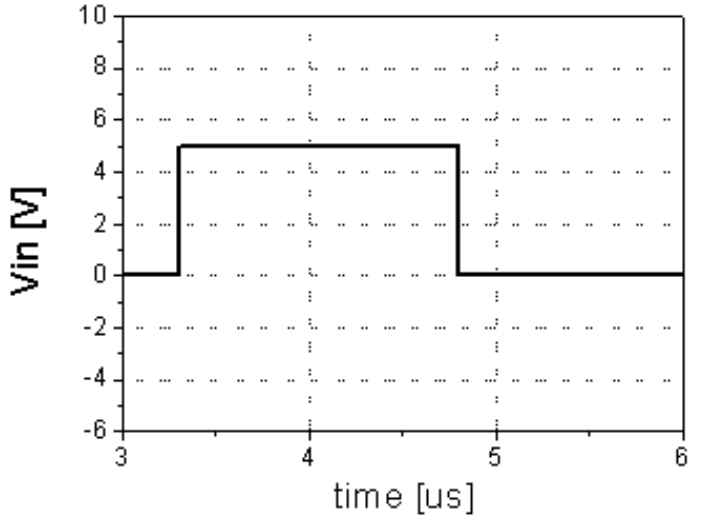

(a) 주기 펄스 입력 신호

(a) Periodic pulse input signal

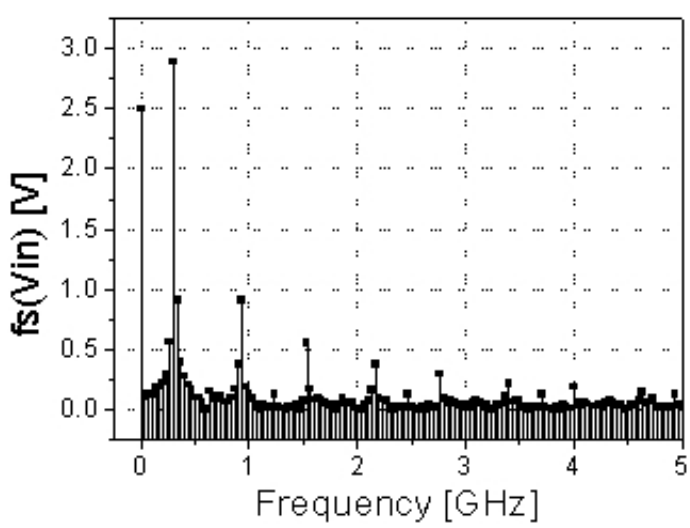

(b) 입력 신호의 퓨리에 변환

(b) Fourier transform of input signal

그림 6. 주기 펄스 입력 신호 및 이 신호의 퓨리에 변환

Fig. 6. Periodic pulse input and its Fourier transform.

가 인가되었을 때, Case 1_y, Case 2_y 그리고 Case $2 \mathrm{x}$ 세 가지 경우에 대한 ADS 시뮬레이션 결과를 보여 준다. Case 1_y와 Case 2_y는 slot 개구가 y방향 으로 있을 때 $\mathrm{PCB}$ 위치가 각각 그림 2의 Case 1과 Case 2에 있는 경우의 결과이며, Case 2_x는 그림 2 의 Case 2 경우 slot 개구가 $\mathrm{x}$ 방향으로 있는 경우의 결과이다.

그림 7(a)와 그림 7(b)를 비교해 보면 slot의 방향 이 동일할 때, $\mathrm{PCB}$ 가 함체의 중앙에 있는 경우(Case 2)가 모서리에 있는 경우(Case 1)보다 전체적인 방사 세기가 강한 것을 알 수 있다. 특히 표 1 에 나타낸 $2.236 \mathrm{GHz}, 2.828 \mathrm{GHz}, 3.606 \mathrm{GHz}$ 등의 공진 주파수 근처의 방사 세기는 함체 중앙에 $\mathrm{PCB}$ 가 위치할 때

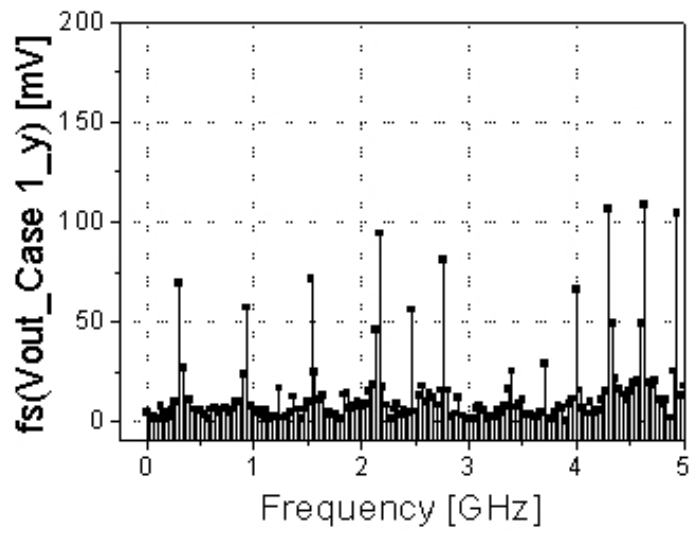

(a) Case 1_y

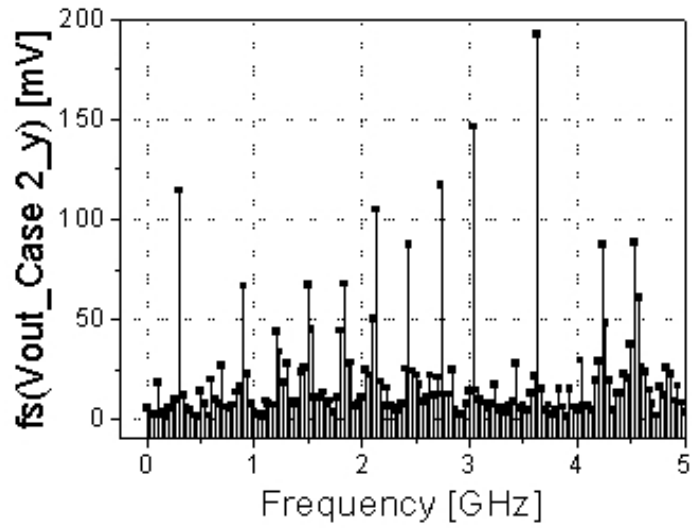

(b) Case 2_y

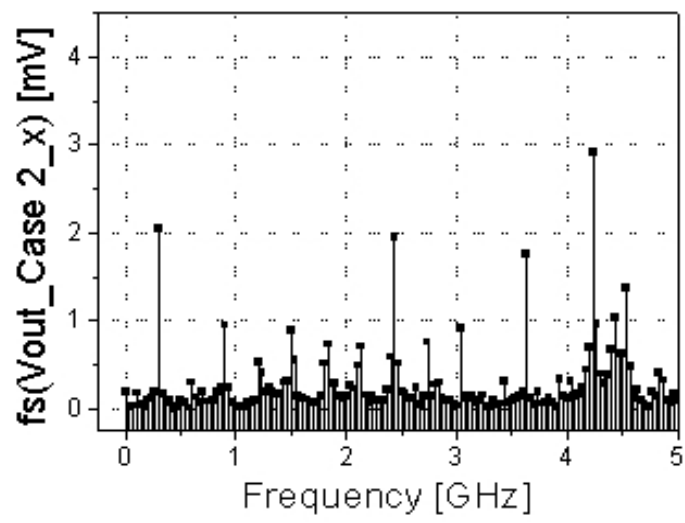

(c) Case 2_x

그림 7. 주기 신호가 인가되었을 때 세 가지 시뮬레 이션 결과

Fig. 7. Three simulation results for periodic input.

큰 것을 확인할 수 있다. 이는 공진 주파수에서 함체 의 파동 임피던스 값이 함체의 가운데 부분에서 크 
게 나타나는 반면에, 모서리 부분은 경계조건에 의해 전계의 크기가 작아져 파동 임피던스 값이 상대적으 로 작아지게 되기 때문이다. 따라서 Case 2의 경우에 $\mathrm{PCB}$ 를 흐르는 신호가 함체와 slot에 더 많이 결합되 게 되어 방사 세기도 더 커지게 된다. 반면, 4.123 $\mathrm{GHz}, 4.472 \mathrm{GHz}$ 등의 공진 주파수 근처의 방사 세기 는 함체 모서리에 $\mathrm{PCB}$ 가 위치할 경우가 더 크게 나 타난다. 이는 위의 주파수에서 함체 중앙의 파동 임 피던스 값이 최소가 되어 Case 2의 경우에 방사 세 기가 Case 1에 비해 상대적으로 약해지기 때문이다.

$\mathrm{PCB}$ 의 위치가 동일하고 slot의 방향이 다른 경우, 그림 7(b)와 그림 7(c)를 비교해 보면 $\mathrm{y}$ 축 방향 slot이 있는 함체의 방사 세기가 $\mathrm{x}$ 축 방향 slot의 방사 세기 보다 약 50 배 정도 큰 것을 알 수 있다. $\mathrm{y}$ 축 slot의 경 우, $(1,1,0)$ 모드 공진에서는 slot이 위치한 지점에서 전계가 가장 커 slot의 전계 분극성(polarizability)이 커지게 되어 방사가 크게 일어난다. 또한, $(2,1,0)$ 모드 공진에서는 slot이 있는 지점이 전계가 최소가 되지만, 자계가 최대가 되고 slot 방향과 자계 방향이 같게 되어 자계 분극성이 커져서 방사가 크게 일어 나게 된다. $\mathrm{x}$ 축 slot의 경우, $(2,1,0)$ 모드 공진에서 는 자계가 $\mathrm{x}$ 방향으로 놓이게 되어 자계 방향과 slot 방향이 수직이 되어 자계 분극성이 작기 때문에 방 사가 상대적으로 작게 일어나게 된다 ${ }^{[9]}$. 따라서 $\mathrm{x}$ 축 방향의 slot인 경우보다 $\mathrm{y}$ 축 방향의 slot인 경우가 더 큰 방사 세기를 갖게 되는 것이다.

다음은 스위칭 잡음이 포함된 입력 신호의 경우 에 대해 살펴보자. 그림 8은 참고문헌 [8]의 DC-DC 컨버터 등가회로를 이용하여 $\mathrm{ADS}$ 시뮬레이션을 통 해 얻은 링잉(ringing) 형태의 스위칭 잡음이 포함된 주기 입력 신호 및 이 신호의 퓨리에 변환을 나타낸 것이다. 그림 8(b)도 그림 6(b), 7과 같이 $\mathrm{ADS}$ 의 fs 함 수를 이용하여 얻었다.

그림 9는 $\mathrm{PCB}$ 의 위치 및 개구의 방향에 따른 $\mathrm{ADS}$ 시뮬레이션 결과를 보여 준다. 전 주파수 대역 에서 그림 7의 경우보다 방사 세기가 상대적으로 크 게 나타나지만, 캐리어 주파수, 하모닉 주파수와 공 진 주파수에서는 방사 세기가 약한 것을 알 수 있다.

그림 6의 주기 펄스 입력 신호의 퓨리에 변환과 그림 8의 스위칭 잡음이 포함된 신호의 퓨리에 변환 을 비교해 보면 그림 6에서는 캐리어 주파수와 하모

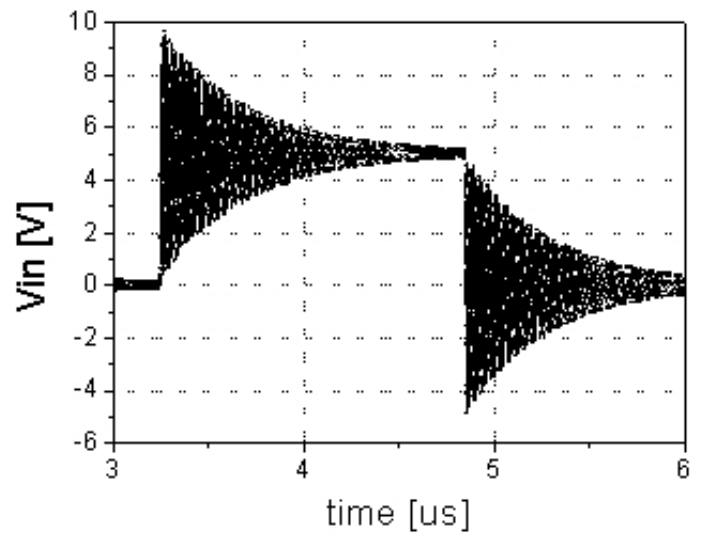

(a) 스위칭 잡음이 포함된 주기 입력 신호

(a) Periodic input signal with switching noise

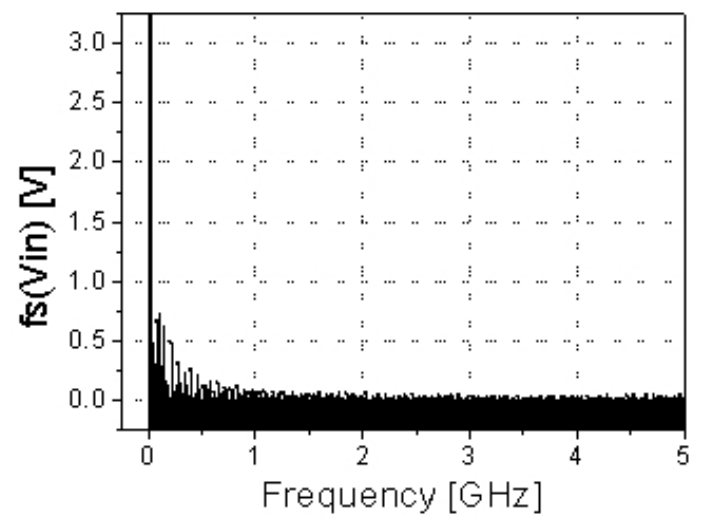

(b) 입력 신호의 퓨리에 변환

(b) Fourier transform of input signal

그림 8. 스위칭 잡음이 포함된 주기 입력 신호 및 이 신호의 퓨리에 변환

Fig. 8. Periodic pulse input with switching noise and its Fourier transform.

닉 주파수에서 전압의 세기가 다른 주파수 대역보다 상당히 크게 나타나고, 그림 8에서는 캐리어 주파수 에서는 전압의 세기가 크지만 하모닉 주파수에서는 다른 주파수 대역과 전압의 크기가 거의 비슷한 것 을 확인할 수 있다. 따라서 그림 7과 그림 9에서 사 용한 주파수 전달 함수는 각각 동일하므로 그림 7에 서는 하모닉 주파수에서의 전압이 크게 나타나고, 그림 9에서는 하모닉 주파수에서의 전압 값은 상대 적 으로 낮게 나타나지만, 그 외의 주파수 대역에서 는 전압이 크게 나타나게 된다.

그림 9(a)와 그림 9(b)를 비교해 보면 그림 7에서와 같이 slot의 방향이 동일할 때, $\mathrm{PCB}$ 가 함체의 중앙에 


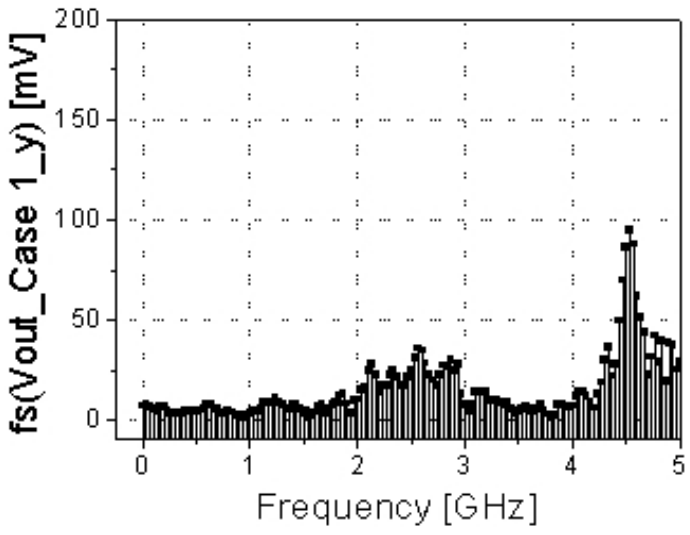

(a) Case 1_y

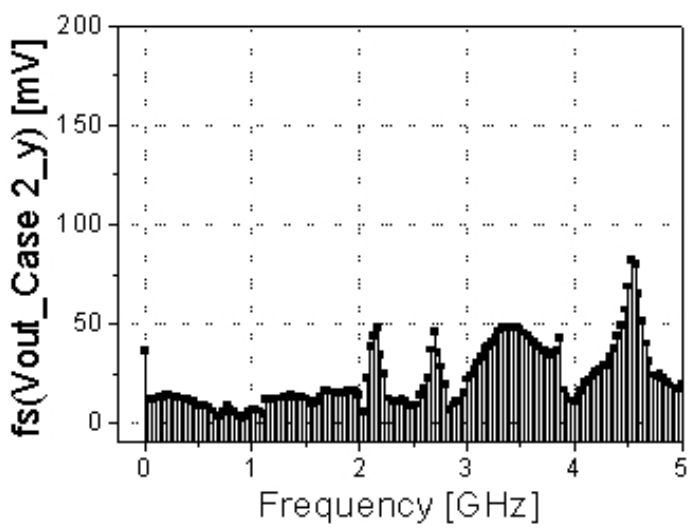

(b) Case 2_y

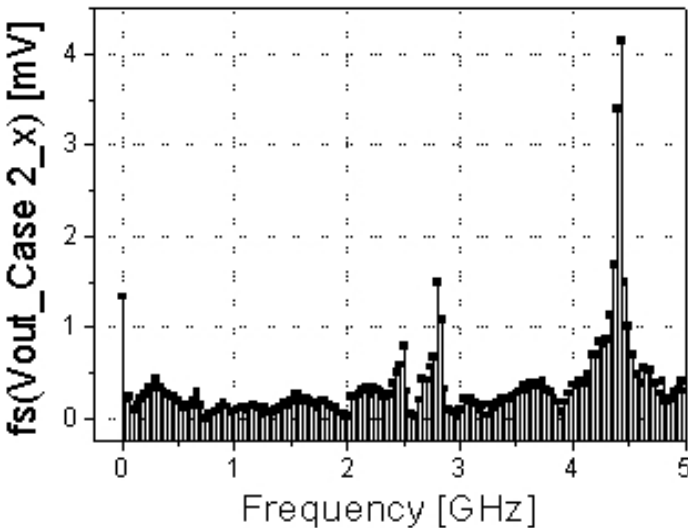

(c) Case $2 \mathrm{x}$

그림 9. 스위칭 잡음을 포함한 신호가 인가되었을 때 세 가지 시뮬레이션 결과

Fig. 9. Three simulation results for switching noise input.

있는 경우가 모서리에 있는 경우보다 전체적인 방사 세기가 강한 것을 알 수 있다.
그림 9(b)와 (c)를 비교해 보면 $\mathrm{PCB}$ 의 위치가 동 일하고 개구의 방향이 다른 경우, 그림 7(b)와 (c)의 비교 결과와 마찬가지로 $\mathrm{y}$ 축 방향으로 slot의 방사 세기가 $\mathrm{x}$ 축 방향 slot의 방사 세기보다 약 50 배 정도 큰 것을 확인할 수 있다.

\section{$\mathrm{IV}$. 측정 결과}

그림 10 은 제작된 $\mathrm{PCB}$ 와 함체의 사진이고, 그림 11 은 측정 셋업을 보여 준다. $\mathrm{PCB}$ 와 함체의 크기 및 재질 등은 시뮬레이션 모델과 동일하며, slot 이외의 방사가 일어날 수 있는 틈새는 금속 박막 테이프를 이용하여 막아주었다. 측정은 대전 고주파 센터의 mobile antenna 측정용 anechoic chamber에서 수행하 였다. $\mathrm{PCB}$ 의 한 쪽 포트에 신호발생기를 이용하여 0 $\mathrm{dBm}$ 신호를 넣어주고, 한 쪽 포트는 $50 \Omega$ 종단시켰 으며, 함체로부터 $3 \mathrm{~m}$ 떨어진 지점에서의 전력을 스 펙트럼 분석기를 이용하여 측정하였다. 측정 시 MWS 시뮬레이션의 입력 신호와 크기가 같은 신호 를 PCB 입력 신호로 하였다. 1 5 GHz 범위에서 표 준 혼 안테나를 이용한 측정 결과를 전계 세기로 변 환시켜 그림 5 의 시뮬레이션과 비교하여 그림 12 에 나타내었다.

$3 \sim 4.5 \mathrm{GHz}$ 정도에서 측정 전계 값이 시뮬레이션

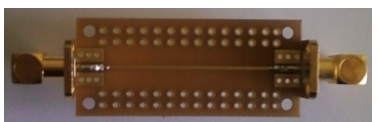

(a) PCB

(a) $\mathrm{PCB}$

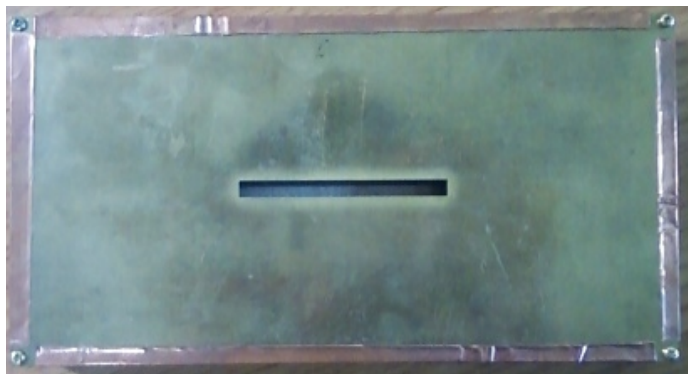

(b) Slot 개구가 있는 함체

(b) Enclosure with slot aperture

그림 10. 제작된 $\mathrm{PCB}$ 와 함체의 사진

Fig. 10. Photograph of the fabricated PCB and the enclosure. 


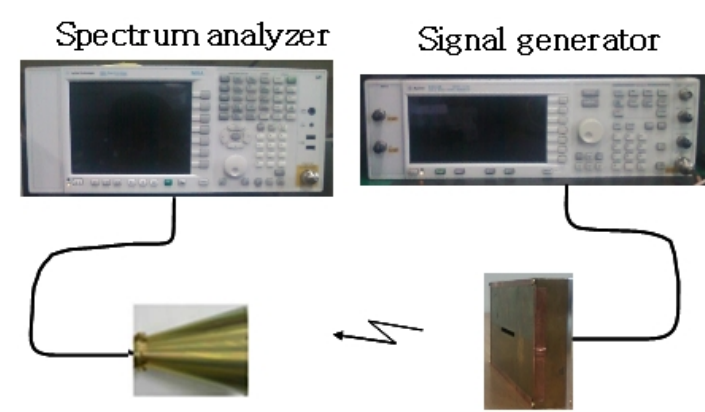

(a) 측정 연결도

(a) Measurement scheme

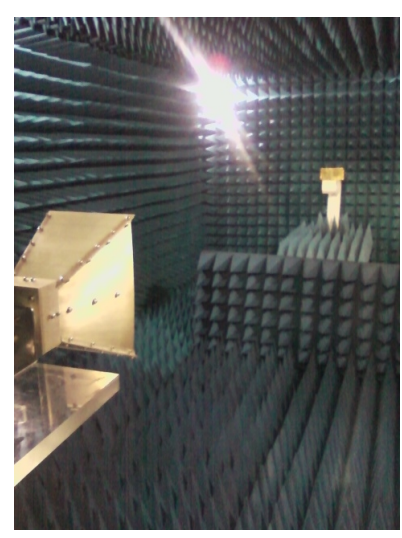

(b) 측정 사진

(b) Measurement chamber picture

그림 11. 측정 셋업

Fig. 11. Measurement setup.

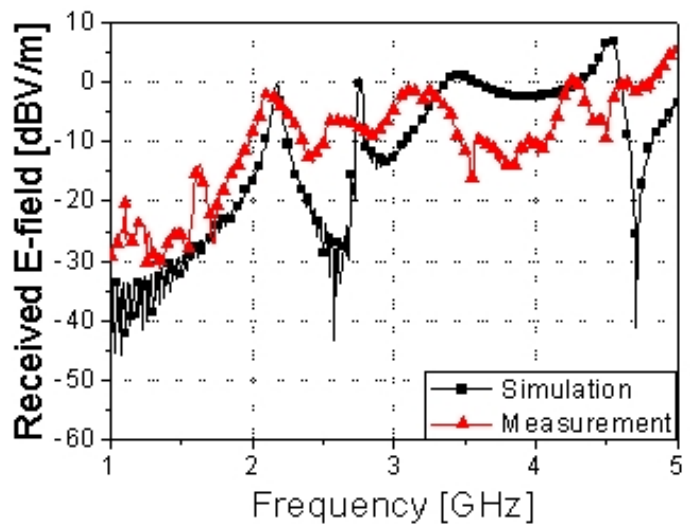

그림 12. 측정 결과와 시뮬레이션 결과 비교

Fig. 12. Comparison of measurement and simulation results.

결과보다 최대 $20 \mathrm{~dB}$ 작게 나오는 것을 제외하면 대 체로 측정 결과와 시뮬레이션 결과가 유사한 방사

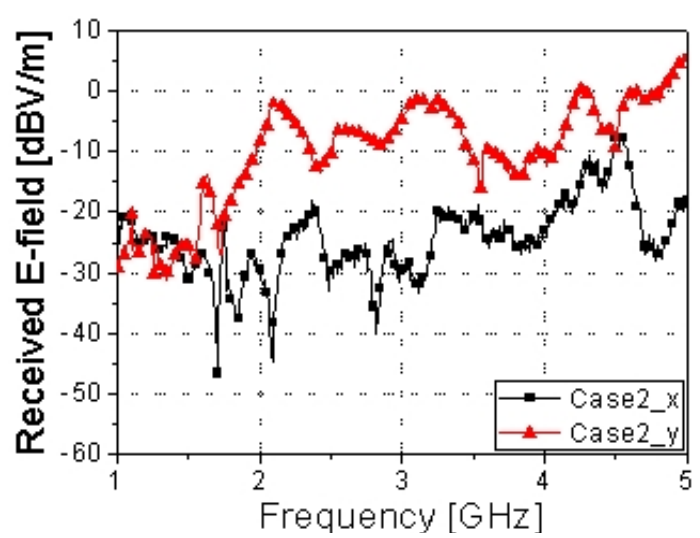

(a) $\mathrm{PCB}$ 의 위치가 같고 slot의 방향이 다른 경우

(a) Different slot direction

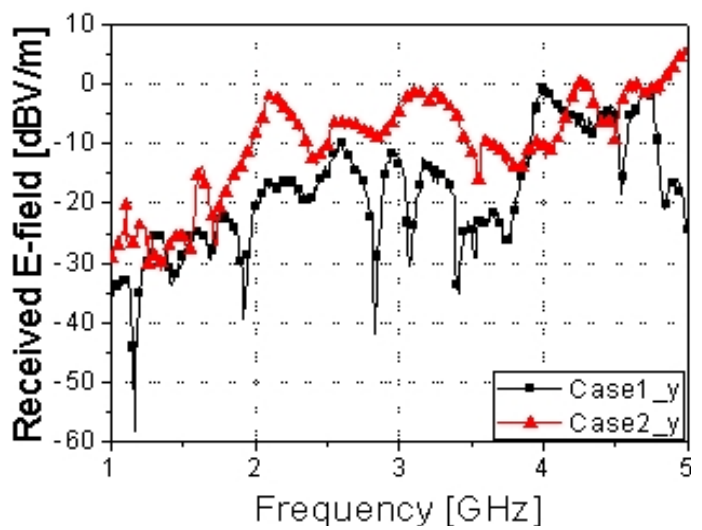

(b) Slot의 방향이 같고 $\mathrm{PCB}$ 의 위치가 다른 경우

(b) Different PCB location

그림 13. 전계 세기 측정치

Fig. 13. Measured electric field intensity.

경향을 보여주는 것을 알 수 있다. 측정 시 수신 안 테나와 함체의 정확한 정렬이 어려워 이것이 일부 오차에 기여했을 것으로 판단하며, 정확한 오차 분 석은 많은 시간과 노력이 더 요구된다고 생각한다.

그림 13 은 전계 세기의 측정치를 보여 준다. 시뮬 레이션과 동일하게 $\mathrm{PCB}$ 의 위치는 같으나 개구의 방 향이 다른 경우, 개구의 방향은 같으나 $\mathrm{PCB}$ 의 위치 가 다른 경우에 대해 비교하였다.

그림 13 에 나타난 것과 같이, $\mathrm{PCB}$ 의 위치가 같고 개구의 방향이 다른 경우 $\mathrm{y}$ 축 방향의 개구를 갖는 함체의 방사 세기가 평균적으로 약 $10 \mathrm{~dB}$, 최대 30 $\mathrm{dB}$ 이상 큰 것을 확인할 수 있다. 또한, 개구의 방향 이 같고 $\mathrm{PCB}$ 의 위치가 다른 경우에도 주파수 대역 
마다 차이가 있지만, 전체적으로 Case 2의 경우가 방 사 세기가 더 큰 것을 확인할 수 있었다.

그림 7과 9의 시뮬레이션 결과와 마찬가지로 $\mathrm{PCB}$ 의 위치가 동일하면 slot 개구가 y방향으로 있는 경 우 더 많은 방사가 일어나는 것을 확인할 수 있으며, slot 개구의 방향이 같고 $\mathrm{PCB}$ 의 위치가 다른 경우, $\mathrm{PCB}$ 가 Case 2의 위치에 있는 경우가 Case 1의 위치 에 있는 경우보다 더 많은 방사가 일어나는 것을 실 험적으로도 확인할 수 있다.

\section{$\mathrm{V}$. 결 론}

본 논문에서는 개구를 갖는 함체 내 $\mathrm{PCB}$ 에 스위 칭 잡음이 포함되지 않은 신호가 인가될 경우보다 능동 소자의 스위칭 잡음이 인가될 때, 캐리어 주파 수와 하모닉 주파수에서는 상대적으로 방사가 약해 지지만, 전체적인 방사 세기는 강하게 나타나는 것 을 확인할 수 있었다. 또한, 함체 내 $\mathrm{PCB}$ 의 위치 및 개구 방향의 변화에 따라 방사 세기가 달라지는 것 을 확인할 수 있었으며, 특히 함체의 공진 주파수에 서 그 영향이 크게 나타나는 것을 알 수 있었다. 시 뮬레이션의 타당성을 검증하기 위하여 제작 및 측정 을 통해 결과를 확인하였다.

본 논문의 결과는 능동 소자로부터 전원을 공급 받는 전자기기 및 전기 자동차 시스템에서의 EMI 문제를 고찰하는데 있어서 기초 자료로 활용할 수 있을 것으로 기대된다.

\section{참 고 문 헌}

[1] M. Li, J. Nuebel, J. L. Drewniak, R. E. DuBroff, T. H. Hubing, and T. P. Van Doren, "EMI from cavity modes of shielding enclosure - FDTD modeling and measurements", IEEE Trans., Electromagnetic Compatibility, vol. 42, no. 1, Feb. 2000.

[2] W. Wallyn, F. Olyslager, E. Laermans, D. De Zu- tter, R. De Smedt, and N. Lietaert, "Fast evaluation of shielding efficiency of rectangular shielding enclosures", 1999 IEEE International Symposium on Electromagnetic Compatibility, vol. 1, pp. 311-316, 1999.

[3] M. Li, K-P. Ma, J. L. Drewniak, T. H. Hubing, and T. P. Van Doren, "Numerical and experimental corroboration of an FDTD thin-slot model for slots near corners of shielding enclosures", IEEE Trans., Electromagnetic Compatibility, vol. 39, pp. 225-232, Aug. 1997.

[4] F. Olyslager, E. Laermans, D. De Zutter, S. Criel, R. De Smedt, N. Lietaert, and A. De Clercq, "Numerical and experimental study of the shielding effectiveness of a metallic enclosure", IEEE Trans., Electromagnetic Compatibility, vol. 41, pp. 202213, Aug. 1999.

[5] Hyoung Seok Jang, Dong Chul Park, "Resonance and radiation characteristics of enclosure with a multilayer PCB and an aperture", Proc. KJJC-AP/EMC/ EMT 2009, vol. 1, pp. 147-150, May 2009.

[6] 장형석, 박동철, "다층 $\mathrm{PCB}$ 공진과 함체 개구 방 사의 해석", 추계 마이크로파 및 전파학술대회, 32(2), p. 162, 2009년.

[7] D. M. Pozar, Microwave Engineering, 3rd Ed., John Wiley \& Sons, pp. 98-117, 2005.

[8] S. Wu, K. Kam, D. Pommerenke, B. Cornelius, H. Shi, M. Herndon, and J. Fan, "Investigation of noise coupling from switching power supply to signal nets", IEEE International Symposium on Electromagnetic Compatibility, pp. 79-84, Jul. 2010.

[9] G. L. Matthaei, L. Young, and E. M. T. Jones, Microwave Filters, Impedance-Matching Networks, and Coupling Structures, Artech House, pp. 230234, 1980. 


\section{장 형 석}

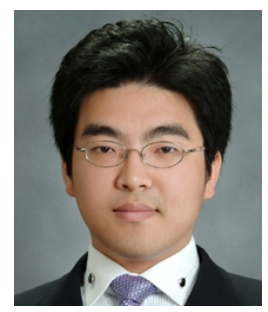

2009년 2월: 충남대학교 전자전파 정보통신공학과 (공학사)

2009년 3월 현재: 충남대학교 전파 공학전공 석사과정

[주 관심분야] $\mathrm{EMI} / \mathrm{EMC}, \mathrm{RF}$ 시스 템 및 부품
이 숭 근

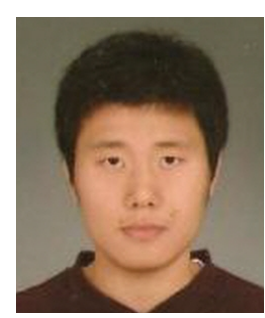

2010년 2월: 충남대학교 전자전파 정보통신공학과 (공학사)

2010년 3월 현재: 충남대학교 전파 공학전공 석사과정

[주 관심분야] $\mathrm{EMI} / \mathrm{EMC}, \mathrm{RF}$ 시스 템 및 부품

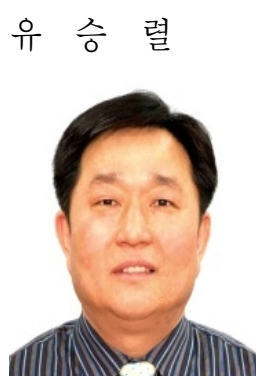

1986년 2월: 충북대학교 물리공학 과 (이학사)

2008년 2월: 충남대학교 전파공학전 공 (공학석사)

1986년 2월 1995년 2월: 국방과학

연구소 EMI/EMC Lab. 연구원

1995년 3월 현재: 자동차부품연구

원 기업지원신뢰성본부 전자기파환경연구센터 센터장 1997년 2월 현재: CISPR D 자동차 분과, ISO TC22 WG

3 전문위원

[주 관심분야] 초고주파 회로설계, $\mathrm{EMI} / \mathrm{EMC}$

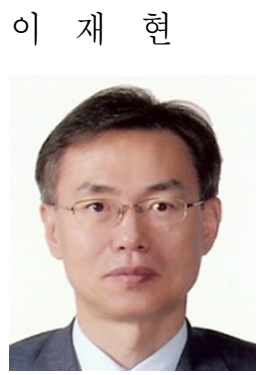

통신연구원 책임연구원

2001년 2월 현재: 충남대학교 전파공학과 교수

[주 관심분야] $\mathrm{PCB}$ 에서의 $\mathrm{EMI} / \mathrm{EMC}$, 위성통신시스템 및 $\mathrm{RF}$ 부품, Magnetostatic Wave Device

1978년 2월: 인하대학교 전자공학 과 (공학사)

1985년 2월: 한국과학기술원 전기 전자공학과 (공학석사)

1993년 2월: 한국과학기술원 전기

전자공학과 (공학박사)

1991년 2월 2001년 2월: 한국전자

\section{김 은 하}

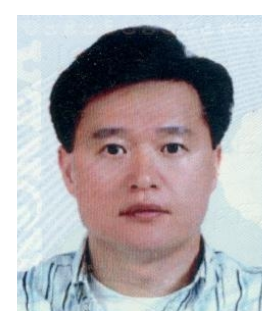

1993년 2월: 서울과학기술대학교 전 자공학과 (공학사)

2004년 2월: 충남대학교 전자공학 과 (공학석사)

2008년 8월: 충남대학교 전파공학 과 박사과정 수료

1990년 2월 1993년 2월: 국립공업

\section{기술원 연구원}

1993년 3월 1996년 2월: (주)마마 연구원

1996년 3월 현재: 자동차부품연구원 기업지원신뢰성본 부 전자기파환경연구센터 팀장

1997년 2월 현재: CISPR D 자동차 분과, ISO TC22 WG

3 전문위원

[주 관심분야] 초고주파 회로 설계, $\mathrm{EMI/EMC}$

.

